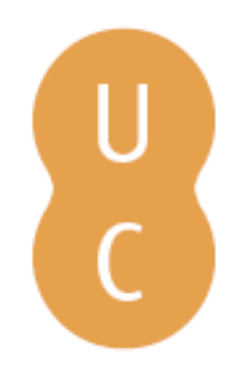

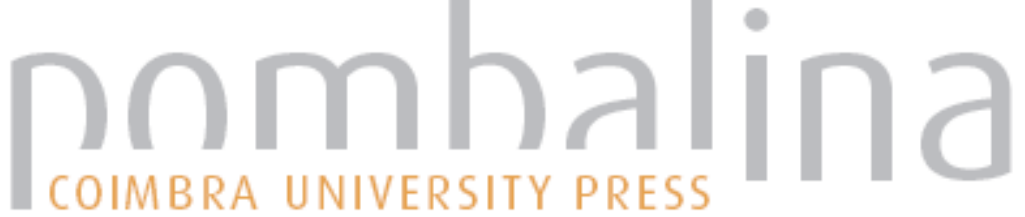

\section{A luz da Mestra}

Autor(es): $\quad$ Klobucka, Anna M.

Publicado por: Imprensa da Universidade de Coimbra

URL

persistente: URI:http://hdl.handle.net/10316.2/42366

DOI: ～～～DOI:https://doi.org./10.14195/978-989-26-1308-6_51

Accessed : $\quad$ 26-Apr-2023 11:37:24

A navegação consulta e descarregamento dos títulos inseridos nas Bibliotecas Digitais UC Digitalis, UC Pombalina e UC Impactum, pressupõem a aceitação plena e sem reservas dos Termos e Condições de Uso destas Bibliotecas Digitais, disponíveis em https://digitalis.uc.pt/pt-pt/termos.

Conforme exposto nos referidos Termos e Condições de Uso, o descarregamento de títulos de acesso restrito requer uma licença válida de autorização devendo o utilizador aceder ao(s) documento(s) a partir de um endereço de IP da instituição detentora da supramencionada licença.

Ao utilizador é apenas permitido o descarregamento para uso pessoal, pelo que o emprego do(s) título(s) descarregado(s) para outro fim, designadamente comercial, carece de autorização do respetivo autor ou editor da obra.

Na medida em que todas as obras da UC Digitalis se encontram protegidas pelo Código do Direito de Autor e Direitos Conexos e demais legislação aplicável, toda a cópia, parcial ou total, deste documento, nos casos em que é legalmente admitida, deverá conter ou fazer-se acompanhar por este aviso.

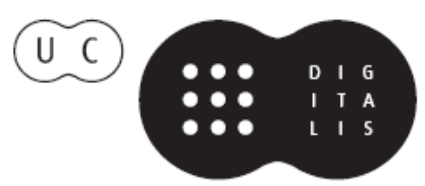





\section{A LUZ DA MESTRA}

Anna M. Klobucka

Começando a defrontar o desafio de escrever este texto, muito pequeno, mas tão difícil - e difícil justamente por ter que ser pequeno, concentrado, seletivo, por não poder reproduzir nos limites da sua focalização o lento decorrer das décadas que desejaria perscrutar -, lembro-me perfeitamente do primeiro texto da autoria de Maria Irene Ramalho que li e sei muito bem quando e em que contexto o li. Era "O Sexo dos Poetas: A propósito de uma nova voz na poesia portuguesa", publicado no número de Inverno de 1989/90 da revista Via Latina, uma reflexão híbrida, entre ensaio académico e recensão (da estreia poética de Ana Luísa Amaral), em que se colocavam questões praticamente ausentes então do mainstream crítico-literário português. Essas questões interessavam-me vivamente, uma vez que estava a iniciar a pesquisa para a minha tese de doutoramento, que viria a concluir em 1993, sobre a construção do sujeito feminino na poesia portuguesa moderna (O Formato Mulber: As poéticas do feminino na obra de Florbela Espanca, Sophia de Mello Breyner Andresen, Maria Teresa Horta e Luiza Neto Jorge), e tinha já percebido que as ferramentas epistemológicas e metodológicas para o meu trabalho teriam de ser, pela maior parte, inventadas de raiz ou adaptadas de modelos colhidos "lá fora", em particular no repertório já tão amplo quanto diverso 
da crítica e teoria literária feminista anglo-americana que, até pela sua própria robustez e multiplicidade das direções em coexistência dialógica, dificilmente se ajustava ao panorama literário, cultural e académico português (para nem mencionar os pressupostos histórico-literários que orientavam o campo anglo-americano como a existência multisecular do protagonismo literário feminino, certamente marginalizado pela perspetiva canónica dominante, mas ainda assim reconhecível e recuperável -, igualmente se afastando das realidades históricas bem distintas que subjaziam à escrita de mulheres em Portugal).

Neste cenário, para mim na altura ainda bastante mais angustiante do que estimulante, com a leitura do ensaio de Maria Irene Ramalho - julgo que encontrado ao acaso, na sala dos periódicos da Biblioteca Nacional, onde se podia folhear livremente os números mais recentes de revistas nacionais e estrangeiras - acendeu-se para mim uma luz pequena, mas intensa, que depressa se tornou um farol, passando a guiar as minhas subsequentes leituras e reflexões. Chamo-lhe aqui "a luz da Mestra" não apenas por este ser um texto de grata homenagem, mas também, e principalmente, por uma razão referencialmente específica, que passo a explicar. A expressão surge nas últimas palavras do poema de Luiza Neto Jorge, "A lume" (publicado originalmente no volume póstumo com o mesmo título), onde realiza uma interrupção do binarismo assimétrico enunciado, e denunciado, na abertura do poema (233):

\author{
Olho-me nos olhos \\ do meu gémeo \\ (seus olhos nos meus \\ ausentes) \\ e sempre vislumbro \\ fixo e refulgente \\ um lume
}


$\mathrm{Na}$ leitura que faço, em $\mathrm{O}$ Formato Mulher, da poética de género (gramatical e sexual) neste poema, situando-o no contexto global da poesia de Luiza Neto Jorge e em justaposição com o soneto "La mort des amants" de Baudelaire, a conclusão de "A lume" representa uma reterritorialização da dicotomia de (re)conhecimento inicialmente evocada em "A Lume":

\author{
Porém o esplendor \\ no espelho alastra \\ como na pupila \\ a luz da Mestra
}

O metafórico par feminino de "pupila" e "Mestra" surge aqui - isto é, na minha leitura alegorizante deste processo - como uma interrupção calmamente explosiva do circuito restrito de comunicação e conhecimento (binário, heteronormativo, totalizante), colocando a possibilidade de uma outra epistemologia relacional (motivo, aliás, recorrente na poesia de Luiza Neto Jorge, com a sua insistência antinormativa - "Não aceito as classes zoológicas" - e incitação às "revoluções de matéria"). E é também como uma interrupção epistémica - tão serenamente ponderada quanto radical - que posiciono a intervenção intelectual de Maria Irene Ramalho, tanto na área dos estudos literários e feministas em Portugal como no meu próprio percurso de aprendizagem e construção de conhecimentos, no qual a leitura dos seus textos tantas vezes teve um papel decisivamente importante. E não posso deixar de referir, também, que esta relação de comunicação por via de textos académicos chegou a ser enriquecida, apenas um pouco mais tarde, pela relação travada pessoalmente, quando a Maria Irene visitou a Universidade de Harvard em 1991, a convite de Helen Vendler, crítica e estudiosa celebrada da poesia norte-americana, com uma conferência sobre "Anglo-American Poetics: From Whitman to Pessoa" (a que se seguiu 
uma receção e o meu emocionado prazer em vir a ser apresentada à conferencista, que se revelou amabilíssima e generosamente interessada no meu trabalho). Aí acendeu-se um outro farol, iluminando outros caminhos (pessoanos e não só) que também continuo ainda a percorrer - sempre atenta aos ensinamentos de Maria Irene Ramalho e sempre grata pela luz da Mestra.

\section{Obras citadas}

Koblucka, Anna, O Formato Mulber: A emergência da autoria feminina na poesia portuguesa. Coimbra: Angelus Novus, 2009.

Jorge, Luiza Neto, Poesia. 1960-1989. Lisboa: Assírio \& Alvim, 1993.

Santos, Maria Irene Ramalho de Sousa, "O Sexo dos Poetas: A propósito de uma nova voz na poesia portuguesa". Via Latina. Coimbra: SHJ/AAC, Inverno de 1989/90. 122-24. 